\title{
IAMJ
}

INTERNATIONAL

AYURVEDIC

MEDICAL JOURNAL

\section{UNDERSTANDING THE PATHOGENESIS AND PREVENTION OF BHAGANDARA IN TERMS OF SHAT KRIYAKALA - A BRIEF REVIEW}

\section{Sahana S Joshi ${ }^{1 *}$, Shivalinagappa J Arakeri ${ }^{2}$, Mohasin Kadegaon ${ }^{3}$, Geetanjali Hiremath ${ }^{4}$}

${ }^{1}$ PG Scholar Department of Shalya Tantra, Taranath Government Ayurveda Medical College and Hospital, Ballari, Karnataka. India

${ }^{2}$ Professor and Head, Department of Shalya Tantra, Taranath Government Ayurveda Medical College and Hospital, Ballari, Karnataka. India

${ }^{3}$ Assistant professor, Department of Shalya Tantra, Taranath Government Ayurveda Medical College and Hospital, Ballari, Karnataka. India

${ }^{4}$ Assistant professor, Department of Shalya Tantra, Taranath Government Ayurveda Medical College and Hospital, Ballari, Karnataka. India

Corresponding Author: $\underline{\text { sahanajoshisdm@gmail.com }}$

\section{https://doi.org/10.46607/iamj06p5042021}

(Published online: May 2021)

Open Access

(C) International Ayurvedic Medical Journal, India 2021

Article Received: 30/03/2021 - Peer Reviewed: 16/04/2021 - Accepted for Publication: 07/05/2021

\section{Check for updates}

\section{ABSTRACT}

Ayurveda mainly focus on identifying and treating the cause, prevention of further manifestation of disease. Kriyakala is explained in Vrana prashneeya adhyaya of Sushruta Samhita for understanding the pathogenesis of disease. Bhaga, Guda, Basti Pradesha Darana is considered as Bhagandara. The symptoms of Bhagandara affect the quality of life significantly. The disease is mentioned under Ashtamahagadas, the treatment of which is still a challenge for surgeons. Hence in this article an attempt has been made to understand the pathogenesis and prevention of Bhagandara in terms of Shat Kriyakala.

Keywords: Shat kriyakala, Bhagandara, Ashtamahagada 


\section{INTRODUCTION}

"Prevention is better than cure" has always been a gold standard and underlined principle for health. Following Sadvritta and Swasthavritta is one dimension, whereas early diagnosis of the illness in its budding stage and planning treatment accordingly is another important dimension which helps in prevention and further manifestation of disease.

Bhaga, Guda, Basti Pradesha Darana is considered as

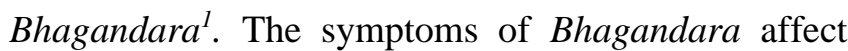
the quality of life significantly and they range from minor discomfort and drainage with resultant hygienic problem. The treatment of Bhagandara is still challenging in this sophisticated era. Hence here is an effort made to understand the pathogenesis of Bhagandara in terms of Shatkriyakala and the role of Shatkriyakala in prevention of Bhagandara.

\section{Shatkriya kala wsr to Bhagandara:}

\section{Sanchaya: (Stage of Accumulation)}

In short Sanchaya can be considered as stage of accumulation. During this stage the doshas get aggravated in their own sites. In Sanchaya period person dislikes the things which caused aggravation of doshas and liking for things opposite to it.

In disease Bhagandara Due to Mithya ahara, vihara (Kashaya, Rukshanna, Asthiyukta Ahara Sevana, Trauma in the local region) Doshas get aggravated in their own sites. In this stage person may show Sthabdha Purna Koshtata, Mandoshmata etc. symptoms based on involvement of Dosha.

If the Doshas are eliminated in this stage of accumulation further progression can be prevented. In short, identification of Sanchaya is done by observing the Dosha Lakshanas, and treatments like Nidana Parivarjana, Samshamana, Langhana-Pachana and Shodhana can be planned.

\section{Prakopa (Stage of provocation)}

It is the second stage of Kriyakala where previously aggravated Doshas get excited and they remain in their own sites. In disease Bhagandra, based on the predominance of Dosha, symptoms like Koshta Toda, Atopa, Vimarga Gamana Of Dosha, Amlika, Pipasa etc can be observed.
This stage demands an immediate action by presenting any of the above-mentioned signs and symptoms. But if the disease is not attended, it will progress to next stage.

\section{Prasara: (stage of spreading)}

In prasara stage the aggravated doshas leave their respective Sthanas and spread to other parts of the body. This process is initiated by Vata alone or in combination with other Doshas.

In Bhagandara, aggravated vata dosha along with other doshas move out of its place and starts spreading to distant places. Person may experience Vayu Vimarga Gamana, Atopa, Paridaha, Arochaka, Avipaka. etc. Dosha sthananusara chikitsa ${ }^{2}$ should be adopted i.e. to correct the Ashaya in which unconcerned Dosha has entered.

\section{Sthana Samshraya (Stage of Localization)}

In this stage the doshas which are travelling all over the body will find a place and gets localized there by manifesting the specific disease which are pertaining to that part. The symptoms of 'would be' disease is seen in this stage and they are called as "Purvaroopa". In case of Bhagandara the vitiated Vata becomes sannivrutta, Sthiribhuta and vitiates the Mamsa and Rakta Dhatus. Dosha along with dhatus get lodged in Guda pradesha (within 1 or 2 angula circumference) ${ }^{3}$. In this stage Purvaroopa of Bhagandara i.e. Kati, Kapala Vedana, Kandu, Daha and Shopha at Guda Pradesha can be seen ${ }^{4}$. The treatment can be planned accordingly.

\section{Vyakta: (Stage of Manifestation)}

Acharya Dalhana calls this stage as "Stage of manifestation of disease". The signs and symptoms are clearly manifested and will denote that disease. This stage is also called as 'Rupavastha'. The treatment of this disease will be symptom specific or disease specific.

This stage of Bhagandara, the Doshas along with Mamsa and Shonita which are lodged in Guda Pradesha produces Pidaka associated with different types of Vedana ${ }^{6}$. 


\begin{tabular}{|l|l|l|}
\hline Sl.No & Dosha involved & Lakshana \\
\hline 1 & Vataja (Shataponaka) & $\begin{array}{l}\text { Pidaka-With Multiple openings (Shataponakavat anumukha), } \\
\text { Vedana- Todadi vedana, Chedana, bhedanavat. } \\
\text { Srava- Accha srava, phena yukta, adhika. }\end{array}$ \\
\hline 2 & Pittaja (Ushtragreeva) & $\begin{array}{l}\text { Pidaka- Ushtra greevakara } \\
\text { Vedana- feels like the guda pradesha is burnt with agni and } \text { kshara, Choshadi vedana. } \\
\text { Srava- Ushna, durgandha. }\end{array}$ \\
\hline 3 & Kaphaja (Parisravi) & $\begin{array}{l}\text { Pidaka- Shukla, sthira, samrambhi, kathina } \\
\text { Vedana- kandu, } \\
\text { Srava- } \text { Picchila }\end{array}$ \\
\hline 4 & $\begin{array}{l}\text { Sannipataja } \\
\text { (Shambhukavarta) }\end{array}$ & $\begin{array}{l}\text { Pidaka- pada angushta pramana } \\
\text { Vedana- Toda, Daha, Kandu } \\
\text { Srava- Nana vidha varna srava }\end{array}$ \\
\hline 5 & Agantuja (Unmargi) & $\begin{array}{l}\text { Ashtiyukta ahara } \text { gets stuck in guda pradesha leading formation of } \text { Kotha } \text { (secondary to } \\
\text { Kshata), discharge of puya, rudhira and formation of } \text { krimi. }\end{array}$ \\
\hline
\end{tabular}

During this stage Shastra vaidya should look for Bhagandara pidaka lakshanas and appropriate chikitsa should be adopted. Apatarpanadi virekanta ekadasha upakrama, Shodhana, Rakta mokshana are some of the treatment modalities explained for Apakwa Bhagandara pidaka ${ }^{6}$.

If Bhagandara pidaka is not treated / neglected at this time, it will enter into pakwa avastha then Sneha, Avagaha swedana, Eshana-patana followed by Kshara karma should be performed.

\section{Bheda: (Stage of Differentiation)}

When the disease is not treated in vyaktavashta, dosha vitiation will have further progression, which leads to manifestation of complications in this stage.

In Bhagandara the tract goes deeper by vitiating the deeper dhatus, ashayas. This communicates Bhaga, guda and Basti pradesha. Upadravas like srava of Vata, Mutra, purisha and retas from opening? ${ }^{7}$. If this stage is also neglected the disease will become Asadh$y a$.

\begin{tabular}{|c|c|c|c|}
\hline Sl.No & Name of Kriyakala & Clinical Significance in Terms Of Bhagandara & Treatment Principles \\
\hline 1 & Sanchya & Aggravation of Vata in their own sites & $\begin{array}{l}\text { Nidana parivarjana, Samshamana, } \\
\text { langhana-pachana, samshodhana }\end{array}$ \\
\hline 2 & Prakopa & Aggravated vata becomes excited & $\begin{array}{l}\text { Nidana parivarjana, Samshamana, } \\
\text { langhana-pachana, samshodhana }\end{array}$ \\
\hline 3 & Prasara & $\begin{array}{l}\text { Aggravated vata combines with other doshas } \\
\text {,Mamsa, shonita and moves out of its place }\end{array}$ & Dosha sthananusara chikitsa \\
\hline 4 & Sthana samshraya & $\begin{array}{l}\text { Vata along with other dushyas take sthana sam- } \\
\text { shraya in Guda pradesha (within 1-2 angula) }\end{array}$ & Purva roopa should be treated \\
\hline 5 & Vyakta & $\begin{array}{l}\text { Formation of Bhagandara pidaka, if not treated it } \\
\text { will produce Bhagandara. }\end{array}$ & $\begin{array}{l}\text { Ekadasha upakrama } \\
\text { Shodhana } \\
\text { Rakta mokshana } \\
\text { Sneahana-swedana-eshana-patana- } \\
\text { kshara karma. }\end{array}$ \\
\hline 6 & Bheda & $\begin{array}{l}\text { Upadrava (Vata, mutra, purisha, retas srvava } \\
\text { from opening) }\end{array}$ & Asadhya \\
\hline
\end{tabular}




\section{DISCUSSION}

Kriya means Chikitsa; kala means proper time / stage of disease. Making proper diagnosis and adopting the chikitsa at proper stage / time is considered as Kriyakala. It has been explained in Vrana prashneeya Adhyaya of Sushruta samhita ${ }^{9}$ for understanding the pathogenesis of vranashopha and vrana, which can be utilized for understanding the pathogenesis of other disease too. Sanchaya, prakopa, prasara are considered to be pre-diseased stage of Samprapti. Where the doshas will aggravate from their own place and spread all over the body. 'Prevention is better than cure' can be easily achieved in this stage. Sthana samshraya and Vyakta are disease stage of Samprapti, where we will get purvaroopa and roopa avastha of Bhagandara. Bheda acts as post disease stage of Samprapti, where there will be presence of complications with poor prognosis. Knowledge of Shat kriyakala helps in identifying the early symptoms of Bhagandara ie, formation of pidaka, kati kapala veda, kandu, daha and shopha in guda pradesha. Planning the treatment according to the stage of disease ie, Shodhana, ekadasha upakrama, Raktamokshana, shatra karma, ksharakarma will prevent the further manifestation of disease and improves the quality of life.

\section{CONCLUSION}

The art of understanding of disease, making an accurate diagnosis and tracking each and every stage of pathogenesis of disease is a must for all medical sciences. Shat kriyakala are appropriate time periods to take action or plan/ implement treatment includes diagnosis of disease at six different stages of its manifestation. Disease is a process of ever-changing manifestation, a process which may end in recovery or death. Though the disease Bhagandara is included under Ashtamahagadas, proper understanding of Bhagandara in terms of shat kriyakala helps in prevention of further progression. Ayurveda gives importance for identifying the cause and treating the condition in an early stage. This can be achieved by adopting the principles of Shat kriyakala.

\section{REFERENCES}

1. Acharya Sushruta. Sushruta Samhita. (Nibandha sangraha commentary of Dalhanacharya and Nyaya chandrika commentary of Gayadasa), translated by K.K. Thakral Reprint edition; Chaukambha orientalia, Varanasi, 2019; Nidana sthana, chapter 4, verse no3, 737 pp

2. Acharya Sushruta. Sushruta Samhita. (Nibandha sangraha commentary of Dalhanacharya and Nyaya chandrika commentary of Gayadasa), translated by K.K. Thakral Reprint edition; Chaukambha orientalia, Varanasi, 2019; Sutra sthana, chapter 21, verse no 31, $257 \mathrm{pp}$

3. Acharya Sushruta. Sushruta Samhita. (Nibandha sangraha commentary of Dalhanacharya and Nyaya chandrika commentary of Gayadasa), translated by K.K. Thakral Reprint edition; Chaukambha orientalia, Varanasi, 2019; Nidana sthana, chapter 4, verse no5, 738 pp

4. Acharya Sushruta. Sushruta Samhita. (Nibandha sangraha commentary of Dalhanacharya and Nyaya chandrika commentary of Gayadasa), translated by K.K. Thakral Reprint edition; Chaukambha orientalia, Varanasi, 2019; Nidana sthana, chapter 4, verse no4, 738 pp

5. Acharya Sushruta. Sushruta Samhita. (Nibandha sangraha commentary of Dalhanacharya and Nyaya chandrika commentary of Gayadasa), translated by K.K. Thakral Reprint edition; Chaukambha orientalia, Varanasi, 2019; Nidana sthana, chapter 4, verse no5,6,7,8,9, 738- 741pp

6. Acharya Sushruta. Sushruta Samhita. (Nibandha sangraha commentary of Dalhanacharya and Nyaya chandrika commentary of Gayadasa), translated by K.K. Thakral Reprint edition; Chaukambha orientalia, Varanasi, 2019; Chikitsa sthana, chapter 8, verse no4, 285 $\mathrm{pp}$

7. Acharya Sushruta. Sushruta Samhita. (Nibandha sangraha commentary of Dalhanacharya and Nyaya chandrika commentary of Gayadasa), translated by K.K. Thakral Reprint edition; Chaukambha orientalia, Varanasi, 2019; Nidana sthana, chapter 4, verse no5, 738 pp

\section{Source of Support: Nil \\ Conflict of Interest: None Declared}

How to cite this URL: Sahana S Joshi et al: Understanding The Pathogenesis And Prevention Of Bhagandara In Terms Of Shat Kriyakala- A Brief Review. International Ayurvedic Medical Journal \{online\} 2021 \{cited May, 2021\} Available from:

http://www.iamj.in/posts/images/upload/2909_2912.pdf 